УДК 821.163.41.09:398"18”

https://doi.org/10.18485/msc50.2019.1.ch46

\author{
Драгиша Живковић
}

\title{
НАРОДНА ФАНТАСТИКА У ТКИВУ СРПСКЕ УМЕТНИЧКЕ ПРИПОВЕТКЕ ДРУГЕ ПОЛОВИНЕ ХІХ ВЕКА
}

Специфичност развијања и конституисања сваке националне литературе огледа се и може се показати на разним и многим елементима уметничке структуре књижевних дела. Овом приликом хтео бих то да покажем на једном од тих елемената, наиме - на начину на који је народна фантастика продирала у ткиво српске уметничке приповетке.

Ако усвојимо општеприхваћену поставку да је „романтизам” „нова врста књижевности” која се јавља на прелазу из 18. у 19. век и да је једна од главних његових карактеристика „враћање сваког народа свом властитом старом духу", онда и српски романтизам почиње негде већ у првој и другој деценији 19. века, са пламеним хердеровским одушевљењем за народност у одама Лукијана Мушицког, са историјским романима барокног типа Милована Видаковића, у којима је тенденција историзма врло јако наглашена, и са револуционарном делатношћу Вука Караџића у правцу одуховљења појма народности као „духа нације”. Разуме се, тај српски романтизам има своје варијетете; ако је код Вукових претходника више предромантичног, хердеровског типа, са јако наглашеним свесловенским одушевљењем, код Вука и његових следбеника он је дубље националан и аутохтон, заснован на живој традицији духовног потенцијала српског народа, на народном (усменом) стваралаштву као јединој непрекинутој линији српске књижевне класике. Разуме се, даље, да је тај српски романтизам врло хетероген у својим теоријским концептима, из чега је и проистекла жестока борба између Вука и његових противника. Али без обзира на те сукобе или, боље речено, упркос њима романтичарска тенденција постоји код свих значајнијих српских писаца прве половине 19. века, само што се она манифестује на разне начине, зависно од теоријских концепата од којих поједини српски писци полазе: од Хердера, и даље - од Жана Паула и немачких постромантичних теоријских поставки, од Гетеа и Шилера, 
од Колара и Штура, и најзад - од нове националне, вуковске платформе, која се већ потпуно оформљује око средине века.

Романтизам почиње, дакле, већ са првим деценијама 19. века, али се он у српској књижевности стваралачки конституише током целог 19. века, доживљавајући књижевно-уметничку зрелост и процват у неким делима српских писаца и из друге половине века и спајајући се крајем века са неким тенденцијама постреалистичке, натуралистичке и симболистичке књижевности. С друге стране, неке реалистичке тенденције запажају се у њој још у првој половини века, са прихватањем бидермајерских тежњи ка проширењу концепта литературе (мемоари, историја, поучни списи) и ка уношењу стварносних елемената у лепу књижевност (комедије Јована Стерије Поповића), да би се у другој половини века конституисале у посебан бидермајерски (Ј. Игњатовић, К. Трифковић) и народњачки (М. Глишић, Ј. Веселиновић и други представници „српске сеоске приповетке”) реализам. Тај реализам траје напоредо са романтичарским тенденцијама и образује сложен сплет српске приповедне прозе 19. века: бидермајерске романе Ј. Игњатовића, историјску валтерскотовску прозу Ст. Митрова Љубише, народњачко фолклорно приповедање J. Грчића Миленка, М. Ђ. Милићевића, М. Глишића и J. Веселиновића, психолошко-аналитичку новелу Л. Лазаревића и И. Вукићевића, мопасанско-натуралистичку варијанту С. Матавуља.

У контексту свих ових сложених периодизацијских кретања у српској књижевности ми ћемо овом приликом издвојити само један елеменат: удео фантастике, и то фантастике народне бајке, у структури српске уметничке новеле 19. века. „Фантастично” и „окултно” једна је од битних одлика романтизма, који га је наследио не само из 18. века (енглески и француски предромантизам, немачки Sturm und Drang) него чак и из класичне старине, из „орфичке”, „оргијастичке” стране хеленске цивилизације. Српски писци и теоретичари из прве половине 19. века знали су за ту страну немачке и европске романтике; међутим, у својој уметничкој пракси они су избегавали елементе „чудесног” и „фантастичног” не само у својим прозним радовима него чак и у стихованим књижевним творевинама. Неколико изузетака од тога као да потврђују правило да су српски писци у првој половини века, вуковци и невуковци, много ближи „рационалистичком” поимању света него митском, мистичном и окултном. Изузетак од тога чини неколико бољих и најбољих писаца онога доба: С. Милутиновић Сарајлија, Ј. Суботић, П. Петровић Његош, који уносе елементе фантастичног само у стиховану форму: Сарајлија у својим епским и драмским творевинама; Суботић у балади Сабља-момче, 
ивет-девојче и Његош у религиозном спеву са библијским мотивом о борби Сатане против Бога - у Лучи Микрокозма.

Вук Караџић је осетио недостатак овога елемента у српској приповедној прози онога времена. У својој „Даници” за 1829. годину он даје кратак садржај једне народне легенде из околине Космаја под веома карактеристичним насловом: Грађа за леп српски роман и позива српске писце да се у своме књижевном стварању користе легендама и бајкама нашег народног, усменог стваралаштва. Додуше, из Вукових речи не види се толико да он инсистира на елементу „чудесног”, колико на елементу „народског” у стварању, али само позивање писаца да се угледају на усмено приповедно стварање могло је да их упути на све врсте народног приповедања (легенде, бајке, митове). Овај Вуков позив уродио је убрзо плодом: Милош Лазаревић, брат познатог драматичара тога доба Лазара Лазаревића, објављује већ 1831. године, у Будиму, свој роман Племенита и силна тьубав, у чијој се фабуларној основици налази баш ова легенда коју препоручује Вук Караџић.

Па ипак, требало је да прође пуних четрдесет година па да српски новелисти почну да уносе елементе фантастике у своју нарацију. Међу првима био је песник и прозаист Јован Грчић Миленко, који у два своја прозна рада: Гостионица код „Полу-звезде” (1868) и Сремска ружа (1869) уноси елементе фантастике из народне бајке, и тиме отвара пут Глишићу, Веселиновићу, Ранковићу и другима да своју слику сељачког живота употпуне и уношењем народне фантастике у њу. Стилски облик народног причаоца о ђаволима, вампирима, вукодлацима и свим „нечастивима" преузео је Грчић несумњиво од Гогоља. Гогољ је 50-их и 60-их година био необично познат и омиљен писац код Срба, а преводи Гогоља из пера Ђорђа Поповића, уредника главних књижевних листова у то доба - „Седмице” и „Данице”, одиграли су не малу улогу у формирању српске уметничке прозе. Грчићев тип народско-фантастичног причања одаје пре свега утицај Гогољеве народске фантастике из првих, украјинских приповедака, стилизованих у облику „сказа”: Вечери на салашу крај Диканке $(1831,1832)$ и Миргорода (1835).

Гогољев утицај још је видљивији у књижевном стварању Милована Глишића, о чему је у нашој књижевној историографији већ писано. Мада фантастика у Глишићеву приповедању има пре свега карактер фолклорне аутентичности, ипак се по учесталости тих елемената у приповедању М. Глишића огледа и својеврсна наклоност овога писца за тематику ове врсте. Његова приповетка После деведесет година (1880), у којој се описује уништавање вампира Саве Савановића, испричана са фином дозом хумора, сва одише тајанством ирационалних сила. Таква је и приповетка 
Вечност (1894) Јанка Веселиновића, у којој је мотив „загробне вечности” спојен с мотивом „умрлог побратима”. На крају и једне и друге приповетке њихови писци нам додуше веле како су ту приповетку чули као причање „старих људи”, односно „старе баке”, али тај оквир у који они стављају своје причање нимало не умањује чињеницу да ови писци обрађују и такву тематику.

Међутим, ако се Глишић и Веселиновић, уносећи у своје приповедање мотиве народне бајке, народног веровања и празноверица, помало ограђују као аутори од те тематике, приписујући је причању „старих бака", један српски писац из последње деценије 19. века, Илија Вукићевић, засноваће фантастичну приповетку у стилизацији народне бајке као посебан жанр у српској књижевности тога доба. Вукићевић је отпочео да пише своје бајке 1894. године, после скоро десетогодишњег бављења приповеткама са тематиком из сеоског и паланачког живота, и за две-три године објавио око десетак бајки: Прича о селу Врачима и Сими Ступици, Како је Настас налбантин тражио срећу, Мала вила, Проклета лепота, Срие и друге. Тај обрт у његовој приповедачкој уметности углавном се тумачи утицајем француских симболиста, и биће да је то образложење тачно. Али стилизација тих бајки у духу народне бајке носи очевидан печат народске фантастике и значи непосредно настављање оне линије коју је започео Јован Грчић, а коју су продужили Глишић и Веселиновић.

Разуме се, Вукићевићеве интенције са писањем бајки литерарније су природе него Глишићево и Веселиновићево подражавање народној фантастици. У том погледу Вукићевић је много ближи Грчићу него оној двојици, јер и Грчић је желео да елементима фантастике постигне литерарне ефекте: слично Хофману, који увек као да даје неко рационално објашњење фантастичних појава, а опет плете фантомску игру тајанственог са стварношћу, и Грчић постепено припрема читаоца за атмосферу тајанства, које се у почетку приказује као сујеверје простих људи, да би у даљем развијању приповетке оно постало нека слутња судбинске уклетости и проклетства човековог. Вукићевић чак симболизује те ирационалне силе; код њега се више и не ради о ликовима из народног сујеверја: ђаволима, вештицама и вампирима, него о стилизацији збивања којом се сугерира тајанство, слутња и иреално. Чак, у Причи о селу Врачима, најдужој и несумњиво с највећим претензијама писаној бајци, Вукићевић од политичке алегоричности прелази у метафизичку симболику човековог пада у мрачно ђавоље царство.

Из овог прегледа да̂ се наслутити да је српски романтизам, у првим својим фазама, а то значи у првим деценијама 19. века, једноставно избегавао слој ирационалног као тематику за своју новелистику. Додуше, срп- 
ска уметничка проза у првој половини 19. века уопште је слабо развијена; Милован Видаковић, Јован Суботић и Богобој Атанацковић - то су свега три познатија имена српске новелистике тога доба. Њихова проза, стилско-типолошки одређена креће се од историјске прозе типа барокно-витешког романа до сентименталистичке прозе забавно-тривијалног типа и, литерарно гледано, нема неке значајније уметничке вредности. Такође, она нема ни неке уже везе с романтичким концептом литературе, нарочито не са ирационалним слојем романтичарске поетике. Видаковић је чак настојао да рационално објасни све што би наликовало на иреална збивања (случај са појавом „духова” на пустом острву у роману Велимир и Босиљка); Богобој Атанацковић, код кога има доста језивих сцена, има само једну приповетку (Три зелене шиблике) која је, како он вели рађена по „народној сказки”. И тек ће од друге половине века, код неких приповедача и у неким њиховим приповеткама, елементи народне фантастике почети да се јављају у српској новелистици.

Све то говори у прилог нашој основној тези да се слој ирационалног, као и неки други метафизички елементи романтичарске поетике, јављају тек у другој половини века и да се на специфичан начин уткивају у грађу српске уметничке приповетке. У то доба, нарочито од 80-тих година прошог века, ти елементи се јављају удружени и са неким стилским особинама постреалистичке, натуралистичке и симболистичке, поетике. Тако, на пример, код Лазе Лазаревића, најбољег српског новелисте 19. века, мотиви сна и халуцинација почињу да добијају функцију уметничке мотивације у неким његовим приповеткама: Вертер, Ветар, Швабииа. Код Симе Матавуља, једног од најбољих српских представника натурализма мопасановског типа, у приповеткама с краја 19. и с почетка 20. века, јављају се такође мотиви халуцинација, тајанства и страве као основни мотивацијски елементи: Водене силе, Павина симфонија, Привиђена нашег иентлмена, Ђукан Скакаваи и другима. Слично Вукићевићу и Матавуљу, и Светолик Ранковић уноси у своју приповетку Стари врускавац (1899) елементе мистичности као мотивацијске детаље фабуле, причајући о тајанственој вези која постоји између дрвета старе трешње („старог врускавца”) и трију поколења једне сеоске породице. Све те приповетке, дакле, означавају крај српског романтизма-реализма 19. века и представљају најтипичније примере нашег књижевног fin de siècle-a, нашег новелистичког симболизма.

На тај начин и на овом примеру се показује колико је и како српски романтизам трајао кроз цео 19. век и како се за цело време свог трајања стапао са неким елементима поетике предромантизма, реализма и симболизма. Српска новела из друге половине 19. века најбољи је пример 
за то: полазећи од реалистичке тезе о потреби сликања народног живота, са регистровањем многих реалних околности човекова живота и рада, она је, у исто време, задржавала или тек тада развијала и неке црте романтичарске поетике: идеализацију народног живота (идилска компонента у српској приповеци), удео ирационалних сила у томе животу (компонента фантастике у њој) и метафизичко тумачење традиционалних и патријархалних форми тога живота (трансцендентна компонента у приповеткама Лазе Лазаревића), прелазећи крајем 19. и почетком 20. века у књижевни концепт симболизма. Или другим речима речено: Вук Караџић и његово дело служили су још дуго српским писцима свих књижевних праваца 19. века као инспирација за њихово књижевно стварање. 